\title{
HYALURONIC ACID AND PROTEIN IN SIMPLE GANGLIA AND HEBERDEN'S NODES
}

\author{
BY \\ M. W. BEGG* AND J. E. SCOTT \\ From the Medical Research Council Rheumatism Unit, Canadian Red Cross Memorial Hospital \\ Taplow, Maidenhead, Berks.
}

Of the many hypotheses cited to account for the origin of simple ganglia, McEvedy (1962) favoured that of metaplasia in the joint capsule producing adventitious bursae. The contents were supposed to consist of a "synovial fluid" formed from a mixture of dialysate of serum and a secretion of "mucin". Usually the fluid is clear and gelatinous, occasionally straw-coloured, and very similar in appearance to that found in the cystic swellings over Heberden's nodes. An investigation of the fluid from Heberden's nodes (Jackson and Kellgren, 1957) showed the presence of hyaluronic acid, a highly polymerized carbohydrate which characteristically forms thick sticky solutions. It was therefore of interest to identify the soluble components of ganglion fluid in the hope of clarifying the aetiology.

\section{Material}

Fluid from ganglia on the dorsum of the carpus was collected during excision of the lesion in six cases and by direct aspiration in one other. Fluid was aspirated from cystic swellings on the extensor aspect of the distal interphalangeal joints of two patients who presented with typical Heberden's nodes. Clinical details of age, sex, and duration of disease are listed in Table I.

TABLE I

CLINICAL PARTICULARS OF NINE CASES

\begin{tabular}{|c|c|c|c|c|c|}
\hline $\begin{array}{l}\text { Case } \\
\text { No. }\end{array}$ & $\begin{array}{l}\text { Age } \\
\text { (yrs) }\end{array}$ & Sex & $\begin{array}{l}\text { Nature of } \\
\text { Lesion }\end{array}$ & $\begin{array}{c}\text { Duration of } \\
\text { Disease (yrs) }\end{array}$ & $\begin{array}{l}\text { Quantity of } \\
\text { Fluid (mg.) }\end{array}$ \\
\hline $\begin{array}{l}1 \\
2 \\
3 \\
4 \\
5 \\
6 \\
7\end{array}$ & $\begin{array}{l}32 \\
29 \\
57 \\
20 \\
30 \\
27 \\
54\end{array}$ & $\begin{array}{l}\mathrm{F} \\
\mathbf{M} \\
\mathrm{F} \\
\mathrm{F} \\
\mathrm{F} \\
\mathbf{M} \\
\mathrm{F}\end{array}$ & Ganglion & $\begin{array}{c}8 \\
7 \\
9 / 12 \\
9 / 12 \\
6 \text { wks } \\
10 / 12 \\
\text { Not known }\end{array}$ & $\begin{array}{c}64 \\
194 \\
795 \\
262 \\
988 \\
\text { Not measured } \\
\text { Not measured }\end{array}$ \\
\hline 8 & 57 & $\mathbf{F}$ & \multirow{2}{*}{$\begin{array}{l}\text { Heberden's } \\
\text { Node }\end{array}$} & $2 / 12$ & 198 \\
\hline 9 & 64 & $\mathbf{F}$ & & 21 & 151 \\
\hline
\end{tabular}

* Present address: Royal Adelaide Hospital, North Terrace, Adelaide, South Australia.
The fluids were taken into small weighed sterile bottles, and stored at $-20^{\circ} \mathrm{C}$. until required. They were all macroscopically free of blood staining.

\section{Method}

It was not easy to measure small volumes of viscous fluids, and comparisons were therefore made on a weight basis.

The material in the sample bottle was dispersed into $10 \mathrm{ml} .0 \cdot 4 \mathrm{M} \mathrm{NaCl}$ with a small magnetic stirrer. The solution was centrifuged at 3,000 G. for 5 mins., and the supernatant (S1) used for subsequent analysis.

Fractionation and Isolation of Polysaccharide (Scott 1960). - $25 \mathrm{mg}$. cetyl trimethyl ammonium bromideo (in the form of a 10 per cent. w/v aqueous solution) wasadded to S1. In each case the solution remained clear. Distilled water was added dropwise from a burette, with magnetic stirring until a considerable flocculant precipitate appeared. In each case this precipitate first appeared at a sodium chloride concentration of 0.20 to $0.22 \mathrm{M}$. Water was added to a final concentration of $0.1 \mathrm{M}$ $\mathrm{NaCl}$, and the precipitate was centrifuged down. The supernant (S2) was used for spectrophotometry.

The precipitate was dissolved in $2 \mathrm{ml} .2 \mathrm{M} \mathrm{NaCl}$ solution, with stirring at $37^{\circ} \mathrm{C}$. for several hours. $2 \mathrm{ml}$. "AnalaR" isopropanol were added, quickly mixed by inversion and spun, and the supernatant, which was in two layers, was decanted. A translucent jelly-like material was left, which was dissolved in $4 \mathrm{ml}$. distilled water. This solution (HA) was used directly for spectrophotometry, and aliquots were taken for the estimation of uronic acid by the carbazole reaction of Dische (in the modification of Gregory, according to Bitter and Muir, 1962), using glucurone as standard.

The remaining acid glycosaminoglycan was precipitated from the solution HA by cetylpyridinium chloride. The precipitate was dissolved in $2 \mathrm{ml}$. $3 \mathrm{~N} \mathrm{HCl}$ and cetylpyridinium was removed by extracting the solution with chloroform. After hydrolysis at $100^{\circ} \mathrm{C}$. for 15 hrs., the solution was evaporated to dryness in vacuo at room temperature. The residue was dissolved in $3 \mathrm{ml} . \mathrm{H}_{2} \mathrm{O}$ and aliquots were taken for hexosamine 
determination by the reaction of Elson and Morgan according to Kraan and Muir (1957), using a glucosamine standard. The remainder was dried in vacuo and dissolved in $0.1 \mathrm{ml}$. water, and the hexosamines were identified by the method of Scott (1962), using naphthyl isothiocyanate instead of phenyl isothiocyanate

Spectrophotometry.-Ultraviolet spectra were obtained directly on the fluids $S 1, S 2$, and $H A$ in $1 \mathrm{~cm}$. quartz cells using a Unicam SP 500 spectrophotometer.

Protein Analysis.-One sample of ganglion fluid was analysed for total protein by a scaled-down biuret method, using an albumin standard. One sample of ganglion fluid and one sample of Heberden's node fluid were hydrolysed by testicular hyaluronidase for $2 \mathrm{hrs}$. at room temperature, and electrophoresed in boratebarbitone buffer on cellulose acetate strips according to the method of Consden and Smith (1965).

\section{Results}

Polysaccharide Analyses.-These were performed exclusively on solutions HA. In general, the solutions HA had noticeable viscosity, at the dilution of less than 0.05 per cent. hyaluronate. The results are shown in Table II. Glucosamine was present in the solutions HA, to the almost complete exclusion of galactosamine. The spectra of the colour produced on the carbazole reaction were very closely similar to that of the standard glucurone One sample of Heberden's node fluid HA wa titrated with $0 \cdot 2$ per cent. cetylpyridinium chloride solution according to Scott (1960) and assuming onlye. hyaluronate to be present, the concentration in? the original fluid was calculated to be 0.302 per cent $\stackrel{\vec{F}}{\vec{P}}$ w/w.

Protein Analysis.-These were performed or? solutions $S 1$ and $S 2$ by spectrophotometry anc electrophoretically on original fluids 6 and 7 aftep digestion with hyaluronidase.

The electrophoretic strip showed at least 70 per cent. of the protein to be albumin. Using a factor $E_{1}^{1} \mathrm{~cm}$ per cent of 10.0 for a serum protein mixture (Tombs, Souter, and Maclagan, 1959) and subtracto ing the reading at $330 \mathrm{~m} \mu$. from that at $280 \mathrm{~m} \mu$. tक eliminate contributions from turbidity, the figures in Table II were obtained.

The spectra were characteristic of serum proteins showing peak absorption at 280-285 $\mathrm{m} \mu$., whick moved to $290-300 \mathrm{~m} \mu$. on the addition of smals amounts of sodium hydroxide.

After precipitation with cetyltrimethylammoniums solutions S2 were found to contain about 70 per cent of the original $280 \mathrm{~m} \mu$. absorption. On dissolving in? $2 \mathrm{M}$ sodium chloride, the precipitate was shown teo contain the remainder. On precipitation wis

TABLE II

RESULTS OF POLYSACCHARIDE AND PROTEIN ANALYSES

\begin{tabular}{|c|c|c|c|c|c|c|}
\hline \multirow{3}{*}{$\begin{array}{l}\text { Case } \\
\text { No. }\end{array}$} & \multicolumn{3}{|c|}{ Polysaccharide Analysis } & \multicolumn{3}{|c|}{ Protein Analysis } \\
\hline & \multirow{2}{*}{$\begin{array}{l}\text { Hexuronic Acid } \\
(\% \mathrm{w} / \mathrm{w})\end{array}$} & \multirow{2}{*}{$\begin{array}{l}\text { Hexosamine } \\
(\% \mathrm{w} / \mathrm{w})\end{array}$} & \multirow{2}{*}{$\begin{array}{c}\text { Hexosamine } \\
\text { Present }\end{array}$} & \multicolumn{2}{|c|}{ Concentration $(\% \mathrm{w} / \mathrm{w})$ by } & \multirow{2}{*}{ Electrophoresis } \\
\hline & & & & Spectrophotometry & Biuret & \\
\hline 1 & $0 \cdot 25$ & $0 \cdot 18$ & Glucosamine & $1 \cdot 1$ & 一 & 一 \\
\hline 2 & $0 \cdot 13$ & $0 \cdot 11$ & Glucosamine & ++ & - & - \\
\hline 3 & $0 \cdot 10$ & $0 \cdot 13$ & Glucosamine & ++ & 一 & 一 \\
\hline 4 & ++ & $0 \cdot 13$ & Glucosamine & $1 \cdot 2$ & - & - \\
\hline 5 & ++ & 0.09 & Glucosamine & ++ & 一 & - \\
\hline 6 & 一 & 一 & - & $\begin{array}{l}1 \cdot 5 \\
++\end{array}$ & - & $\begin{array}{l}\text { Alb }++ \\
\alpha_{1 \text { glob }} \\
\alpha_{22 \text { glob }} \\
\left.\begin{array}{l}\beta \text { glob }+ \\
\gamma \text { glob }+\end{array}\right\} \text { trace } \\
{ }_{-}\end{array}$ \\
\hline 8 & - & $0 \cdot 32$ & Glucosamine & $2 \cdot 5$ & - & $\left.\begin{array}{l}\text { Alb }++ \\
\alpha_{1} \text { glob } \\
\alpha_{2 \text { glob }} \\
\beta \text { glob }+ \\
\gamma \text { glob }+\end{array}\right\}$ trace \\
\hline 9 & \multicolumn{3}{|c|}{$\begin{array}{c}\text { "Hyaluronate" concentration by cetylpyridinium titration } \\
\qquad=0.302 \% \mathrm{w} / \mathrm{w}\end{array}$} & 0.9 & & \\
\hline
\end{tabular}

Note: The qualitative symbols ++ and + are shown when it was not possible to make a quantitative assessment. A dash $(-$ ) indicates that the estimation was not carried out. 
isopropanol and re-solution in water, the solutions HA showed no significant absorption at $280 \mathrm{~m} \mu$.

\section{Discussion}

A material has been isolated from ganglion fluid with the following properties:

(1) Its solutions are viscous.

(2) It shows only end-absorption in the ultraviolet spectrum.

(3) It contains glucosamine as the only hexosamine.

(4) It contains uronic acid, in approximately equimolar quantities with hexosamine.

(5) Its "critical electrolyte concentration" with cetyltrimethylammonium in sodium chloride solution is $0 \cdot 2 \mathrm{M}$ (Scott, 1960).

(6) It is a substrate of hyaluronidase.

These properties establish the material to be hyaluronate. The complete absence of a precipitate with cetyl trimethylammonium at higher molarities of sodium chloride than 0.2 rules out the presence of highly-polymerized sulphated polysaccharides. The concentration of hyaluronate varies from about 0.25 to 0.6 per cent. $w / w$, with the greater part of the data suggesting 0.3 to 0.4 per cent. $\mathrm{w} / \mathrm{w}$ as the characteristic concentration. This estimate is a minimum, since the two precipitation steps before analysis would be expected to eliminate low molecular weight material. The impression is gained that the isolated material contributes most or all of the characteristic viscosity of the fluids from ganglia and Heberden's nodes. If there are other acidic mucopolysaccharides present (e.g. keratosulphate, chondroitin sulphate, heparitin sulphate, etc.) the concentration must either be low in comparison with the hyaluronate, or they must be very degraded. This conclusion is in accord with that of Jackson and Kellgren (1957) on Heberden's nodes.

Fluids from ganglia and Heberden's nodes also contain proteins which migrate in a pattern qualitatively identical with the serum proteins. Spectrophotometric measurements suggest a concentration range of 1.0 to 2.5 per cent. $w / w$. This is probably a slightly high estimate, since the factor or $E_{1}^{1} \mathrm{cer}$. cent $=10$ at $280 \mathrm{~m} \mu$. (Tombs and others, 1959) is based on a slightly lower albumin globulin ratio than is apparently present. The correction would not be greater than -15 per cent. It is clear that the protein is not linked covalently to the polysaccharide, since the two are easily separated by the mildest physico-chemical means.

The conclusion that Heberden's node fluids contain serum protein is at variance with the findings of Jackson and Kellgren, which is based on: (a) qualitative tests, xanthoproteic, Millon's and ninhydrin;

(b) amino acid content of acid hydrolysates by paper chromatography;

(c) electrophoresis of original fluid on filter paper.

The qualitative tests may not be sufficiently sensitive on small quantities, and we found that electrophoresis of proteins in the presence of undegraded hyaluronate results in gross distortion of the pattern, coupled with decreased sensitivity of the protein stain. The absence of amino acids which Jackson and Kellgren observed is better evidence, and it may be that the protein content of Heberden's node fluid is more variable than that of ganglia fluid.

The concentrations of hyaluronate and protein in ganglion fluid, and also the protein pattern, are similar to those observed in normal synovial fluid (Mäkinen, 1958) and in mesothelioma fluid (Scott, unpublished). In other fluids and gels, hyaluronate occurs along with fine collagen fibres $(e . g$. vitreous humour and Wharton's jelly). It is not known if collagen fibres are present in ganglia and Heberden's node fluid. In all these fluids it is usual to find serum proteins at a concentration of less than half the serum concentration, and with a relative enrichment of albumin to globulin. Thus, the data available do not permit unequivocal conclusions on the aetiology of ganglia, but they do suggest that the fluid is of a kind usually manufactured by cells, such as are found in synovia, vitreous bodies, mesotheliomata, etc., and we are therefore of the opinion that the ganglia do not arise solely by breakdown of locally occurring connective tissue. We consider our findings to be compatible with the structural aspects of the picture of ganglion production favoured by McEvedy (1962).

\section{Summary}

Samples of ganglion fluid from six cases and of Heberden's node fluid from two cases were examined qualitatively and quantitatively for acid mucopolysaccharide and protein content. The two fluids were found to be of similar composition. Hyaluronic acid was present in concentrations of 0.25 to 0.6 per cent. w/w. No other acid mucopolysaccharide was detected. Serum protein was present in concentrations of 1 to 2.5 per cent. $\mathrm{w} / \mathrm{w}$. Electrophoresis on cellulose acetate showed a predominance of albumin, with beta and gamma globulins easily discernible, and traces of $\alpha_{1}$ and $\alpha_{2}$ globulins. 
Our thanks are due to Mr. Maudsley and Mr. Aherne at the Heatherwood Hospital, Ascot, and to Mr. Arden at the King Edward VII Hospital, Windsor, who provided the material.

We are grateful to Dr. R. Consden for the biuret determination and for the electrophoretic data.

\section{REFERENCES}

Bitter, T., and Muir, H. M. (1962). Anal. Biochem., 4, 330.

Consden, R., and Smith, M. (1965). Ann. rheum. Dis., 24, 239.

Jackson, D. S., and Kellgren, J. H. (1957). Ibid., 16, 238.

Kraan, J. G., and Muir, H. M. (1957). Biochem J., 66, $55 \mathrm{P}$.

McEvedy, B. V. (1962). Brit.J. Surg., 49, 585.

Mäkinen, P. (1958). "Synovial Fluid in Rheumatoid Arthritis." Ann. med. exp. Biol. Fenn., 36, Suppl. 7.

Scott, J. E. (1960). Meth. biochem. Anal., 8, 145.

- (1962). Biochem.J., 82, 43P. Unpublished data.

Tombs, M. P., Souter, F., and Maclagan, N. F. (1959). Biochem. J., 73, 167.
L'acide hyaluronique et la protéine dans les kystes péritendineux et dans les nodosités d'Heberden

\section{RÉSƯMÉ}

On examina le liquide des kystes péritendineux en six cas et des nodosités d'Heberden en deux cas en y recher-? chant, qualitativement et quantitativement, le mucopoly saccharide acide et la protéine. On trouva que la compos? sition des deux liquides était similaire. L'acide hyalurō nique y était présent en concentrations de 0,25 à 0,6 pour cent. On n'y décéla aucun autre mucopolysaccharide acide. La protéine sérique s'y trouvait en concentrations? de 1 à 2,5 pour cent. L'électrophorèse sur acétate dę cellulose montra que l'albumine prédominait, leș globulines gamma et beta étaient bien perceptibles et or ${ }^{\text {s }}$ y vit des traces des globulines $\alpha_{1}$ et $\alpha_{2}$.

\section{El ácido hialurónico y la proteina en los quistes} peritendinosos y en los nódulos de Heberden

\section{Sumario}

Se investigó el líquido de quistes peritendinosos erin seis casos y de nódulos de Heberden en dos casos y sér determinaron, cualitativa y cuantitativamente, el muco $N$ polisacirido ácido y la proteina. Se halló que la composi $\vec{A}$ ción de ambos líquidos fué similar. El ácido hialurónicơr fué presente en concentraciones de 0,25 a 0,6 por ciento은 No se encontró ningún otro mucopolisacarido ácido. La proteina sérica fué encontrada en concentraciones de 1 a 2,5 por ciento. La electroforesis sobre acetato de्छ celulosa mostró un predominio de la albumina, corn̆ globulinas gamma y beta bien perceptibles y con huellas de las globulinas $a_{1}$ y $a_{2}$. 